\title{
Defining a Crime Without a Name: The History of Genocide as a Legal Concept
}

\author{
Defendendo um crime sem nome: a história do \\ genocídio como um conceito jurídico.
}

Casey Daggett ${ }^{l}$

\begin{abstract}
:
This paper will explore the historical roots of genocide as a legal concept and its construction in the wake of the Holocaust with the ultimate goal of informing the legal community as to its ongoing nuances and true definition. Although genocide has become a cultural concept, used interchangeably alongside war crimes and crimes against humanity to describe violence against a specific group, it is critical to understand that genocide is a crime. By understanding what genocide truly is and how it came to be the international community will possibly be able to better understand it, and subsequently seek to prevent it.
\end{abstract}

Key-words: Genocide; war crimes; legal concept; Human Rights.

\section{Resumo:}

Este artigo explorará as raízes históricas do genocídio como um conceito legal e sua construção na sequência do Holocausto, com o objetivo final de informar a comunidade jurídica sobre suas nuances e sua verdadeira definição. Embora o genocídio tenha se tornado um conceito cultural, usado alternadamente ao lado de crimes de guerra e crimes contra a humanidade para descrever a violência contra um grupo específico, é fundamental entender que o genocídio é um crime. Compreendendo o que o genocídio realmente é e como ele surgiu, a comunidade internacional possivelmente será capaz de entendê-lo melhor, e subsequentemente procurar preveni-lo.

Palavras-chave: Genocídio; crimes de guerra; conceito jurídico; Direitos Humanos.

1. Articles Editor at Oregon Review of International Law, University of Oregon Law Student Bar Association, Oxford Consortium for Human Rights. 


\section{$\underline{\text { I - Misconceptions of "Genocide" In Current Conflicts }}$}

Immediately upon utterance, the word "genocide" invokes a profound reaction with imagery of the darkest moments of the twentieth century and the depths of human cruelty springing to mind. However, as much as genocide has become a cultural concept, used interchangeably alongside war crimes and crimes against humanity to describe violence against a specific group, it is critical to understand that genocide is a crime. Furthermore, it is a crime that bears a specific definition and requirements. ${ }^{2}$ Subsequently, the legal community should strive to understand the legal definition of genocide as opposed to its cultural conception with the same precision it would apply to other any other crime or charge.

Through examining the history of the creation of genocide, tremendous insight is gained about genocide as a legal concept, specifically its inception by a lawyer named Raphael Lemkin and through the U.N. Convention on the Prevention and Punishment of the Crime of Genocide. A glimpse into the creation of genocide reflects on many of the current issues surrounding the crime, including jurisdiction, connection to war, use alongside similar crimes, and state sovereignty. In order to better understand the significance of the past, however, we need only look to the present.

Two current conflicts embody the common misconceptions about the definition of genocide and the difficult politics surrounding it, the Rohingya conflict and the Yazidi genocide. The Rohingya, a Muslim minority within the Rakhine region of Myanmar, have long been viewed as illegal immigrants by the Buddhist majority and subjected to discrimination and violence. ${ }^{3}$ However, violence against the minority exploded after a Rohingya insurgency group attacked

\footnotetext{
${ }^{2}$ Devrim Aydin, The Interpretation of Genocidal Intent under the Genocide Convention and the Jurisprudence of International Courts, 78 THE J. OF CRIM. L. 1 (2014).

${ }^{3}$ Nahal Toosi, The Genocide the U.S. Didn't See Coming,Politico MagaZine (Mar./Apr. 2018), https:/www.politico.com/magazine/story/2018/03/04/obama-rohingya-genocide-myanmarburma-muslim-syu-kii-217214.
} 
Myanmar's military and killed a dozen officers. ${ }^{4}$ In response, the military savagely cut through Rohingya villages and communities, leading to more than 680,000 Rohingya fleeing to neighboring Bangladesh. ${ }^{5}$

In December $15^{\text {th }}, 2017$, the New York Times published an article detailing the plight of the Rohingya in Myanmar titled "Is This Genocide?"' Within the article, noted human rights advocate and author Nicholas Kristof examined some of the atrocities inflicted upon the Muslim minority community, a community that has long been reviled by both Myanmar and neighbors within the region. ${ }^{7}$ Kristof recounts chilling instances of gang rape, child murder, and arson inflicted upon the Rohingya by Myanmar's military. ${ }^{8}$ In closing the article, Kristof argues that the actions taken against the Rohingya constitute genocide but, notably, does not ever define what genocide is, using it alongside related terms such ethnic cleaning. ${ }^{9}$ A few months later, however, Kristof published another article about the plight of the Rohingya and stated, "This is my fourth trip in four years to cover the Rohingya, a Muslim minority despised in a mostly Buddhist country, and initially I used the term "ethnic cleansing." But along with many human rights monitors, I've come to conclude that what is unfolding here probably qualifies as genocide." 10 Yet again, genocide was never given a specific definition.

In contrast, nations and state actors are often incredibly precise in determining what to label instances of violence and atrocity. In November 2017, then Secretary of State Rex Tillerson addressed the on-going conflict as ethnic cleansing, a departure from the far less critical assessments he had relayed since the violence began in August $2017 .{ }^{11}$ There can be no doubt

\footnotetext{
${ }^{4} I d$. at 1 .

${ }^{5} I d$. at 1.
}

${ }^{6}$ Nicholas Kristof, Is This Genocide?, N.Y. TIMES(Dec. 15, 2017), https://www.nytimes.com/2017/12/15/opinion/sunday/genocide-myanmar-rohingyabangladesh.html.

${ }^{7}$ Eleanor Albert, The Rohingya Crisis, COUNCIL ON FOREIGN REL. (Feb. 9, 2018), https://www.cfr.org/backgrounder/rohingya-crisis.

${ }^{8}$ Kristof, supra note 5, at

${ }^{9} I d$. at 2 .

${ }^{10}$ Nicholas Kristof, I Saw a Genocide in Slow Motion, N.Y. TIMES (Mar. 2, 2018), https://www.nytimes.com/2018/03/02/opinion/i-saw-a-genocide-in-slow-motion.html.

${ }^{11}$ Robbie Gramer, Tillerson Finally Brands Myanmar Crisis 'Ethnic Cleansing', ForeIGN POL'Y, (Nov. 22, 2017), http://foreignpolicy.com/2017/11/22/tillerson-finally-brands-myanmar-crisisethnic-cleansing-rohingya-muslims-war-crimes-genocide-state-department-asia-refugees/. 
that the delay in denouncing the conflict as ethnic cleansing was a purposeful one, given that, as one senior State Department official told reporters, "It is a descriptive term and it carries with it, again, the sense of urgency...It does not require any new obligations, but it does emphasize our concern about the situation." 12 Similarly, in March of 2018, the UN Special Rapporteur on human rights in Myanmar labeled the conflict as genocide, stating "I am becoming more convinced that the crimes committed following 9 October 2016 and 25 August 2017 bear the hallmarks of genocide and call in the strongest terms for accountability." 13 The crisis is currently ongoing, with multiple mass graves being discovered as recently as February 2018. ${ }^{14}$

Yet another recent conflict has resulted in the international community debating how and what to label atrocity. In August 2014, the Islamic State (ISIS) sent fighters into the Mount Sinjar region of Northern Iraq alongside the Syrian border. ${ }^{15}$ The Sinjar region is home to the Yazidis, an ancient, long persecuted religious minority who number roughly 700,000. ${ }^{16}$ The Yazidi religion, believed to have been founded in the $11^{\text {th }}$ century, incorporates elements of Christianity, Judaism, and Zoroastrianism. ${ }^{17}$ This unique blend of faiths has resulted in centuries of Yazidi subjugation and persecution and was at the center of the 2014 ISIS attack. ${ }^{18}$ In its magazine, Dabiq, ISIS labeled the Yazidis infidels and stated its intent to completely annihilate the minority group. ${ }^{19}$

\footnotetext{
${ }^{12} I d$.

${ }^{13}$ Bard Wilkinson, UN official convinced of Myanmar Rohingya 'genocide', CNN (Mar. 12, 2018), https://www.cnn.com/2018/03/12/asia/myanmar-rohingya-un-violence-genocideintl/index.html.

${ }^{14}$ AP finds mass graves, latest evidence of Rohingya genocide in Myanmar, CBS NEWS (Feb. 1, 2018), https://www.cbsnews.com/news/myanmar-mass-graves-latest-rohingya-slaughtergenocide-ap/

${ }^{15}$ Valeria Cetorelli ET AL., ISIS’ Yazidi Genocide, ForEIGN AFF. (June 8, 2017), https://www.foreignaffairs.com/articles/syria/2017-06-08/isis-yazidi-genocide.

${ }^{16}$ Raya Jalabi, Who are the Yazidis and why is Isis hunting them?, THE GUARDIAN (Aug. 11, 2014), https://www.theguardian.com/world/2014/aug/07/who-yazidi-isis-iraq-religion-ethnicitymountains.

${ }^{17} I d$.

${ }^{18}$ Id.

${ }^{19}$ Cetorelli, supra note 14 , at 1 .
}

Revista Juris Poiesis - Rio de Janeiro. Vol.21-n²6, 2018, pg.285 - 303. ISSN 2448-0517 
On August $3^{\text {rd }}$, 2014, ISIS fighters claimed Sinjar City and forced thousands of Yazidis to flee to nearby Mount Sinjar to seek refuge. ${ }^{20}$ The United Nations estimated that over 40,000 Yazidis were hid on the mountain in temperatures as high as 122 degrees Fahrenheit, lacking access to desperately needed aid or medical supplies. ${ }^{21}$ Though international airdrops over the next few days provided water and food, it is estimated that hundreds of Yazidis died before Kurdish forces were able to secure their safety. ${ }^{22}$ Furthermore, those were unable to escape Sinjar City and the surrounding villages suffered tremendously at the hands of ISIS fighters. Men and young boys were systematically separated from their families and those who refused to convert to Islam were executed, their bodies left alongside roadsides and village streets. ${ }^{23}$ Captured Yazidi women and girls were declared the property of ISIS and openly labeled slaves to be purchased by ISIS fighters and affiliates of the group. ${ }^{24}$ Estimates in 2016 placed the number of Yazidi women held as sexual slaves at $3,200 .^{25}$

In response, the UN Human Rights Council categorized the violence against the Yazidis as genocide during its 32nd Session in 2016. The report stated that "ISIS has committed the crime of genocide as well as multiple crimes against humanity and war crimes against the Yazidis, thousands of whom are held captive in the Syrian Arab Republic where they are subjected to almost unimaginable horrors." 26 Notably, the report also addressed the use of genocide "as it exists in the public imagination", noting that the technical, legal definition differs from the common conception. ${ }^{27}$ It further explained that genocide has largely come to signify the intentional killing of mass groups of people, linked inextricably to images of the Holocaust and

${ }^{20} I d$.

${ }^{21} I d$.

${ }^{22}$ Hum. Rts. Council, "They came to destroy": ISIS Crimes Against the Yazidis, U.N. Doc. A/HRC/32/CRP.2 (2016).

${ }^{23} I$. at 8 .

${ }^{24}$ Id. at 11 .

${ }^{25}$ Id. at 2 .

${ }^{26} I d$. at 1 .

${ }^{27}$ Id. at 5 . 
Rwanda, irrespective of the intention behind the killings. ${ }^{28}$ The common conception of genocide, a targeted killing regardless of intentionality, is therefore more akin to crimes against humanity. ${ }^{29}$

A 2016 Hearing before the House Subcommittee on Africa, Global Health, Global Human Rights, and International Organizations similarly emphasized the misconceptions about the legal definition of genocide and the use of related terminology in regards to ISIS atrocities. There, David Crane, a professor of law at Syracuse, argued that ISIS had committed war crimes, crimes against humanity, and possibly genocide. ${ }^{30} \mathrm{He}$ further stated that, "I would just submit respectfully to this subcommittee that 300,000 killed as the result of an international crime don't care whether it is a genocide, crime against humanity, or war crime. So I want to caution our use of terms...I would just caution this subcommittee, when they are considering the war crimes, watch out for tiering and ranking the crimes, as well as understanding that genocide, even though a very serious crime, a crime of crimes, is a difficult and very specific type of crimes..." ${ }^{31}$ In emphasizing the distinctions between, as well as the common blending of, war crimes, crimes against humanity, and genocide, Crane spoke directly to the persistent confusion regarding the legal definition of genocide.

This paper will explore the historical roots of genocide as a legal concept and its construction in the wake of the Holocaust with the ultimate goal of informing the legal community as to its ongoing nuances and true definition. Though arguments about the labeling of human suffering and cruelty may at first glimpse seem pedantic, the precision of legal language can have tremendous ramifications on both current conflicts and their aftermath. ${ }^{32}$ Finally, as David Crane so hauntingly spoke of, victims of genocide do not have the luxury of caring what the actual crime may be labeled, but those in positions of power and influence should strive to speak with clarity and accuracy. The international legal community can better understand, and subsequently seek to prevent, genocide by understanding what is truly is and how it came to be. As Elie Wiesel

\footnotetext{
${ }^{28} I d$.

${ }^{29}$ Crimes Against Humanity, U.N. OfF. ON GENOCIDE PREVENTION AND THE RESP. TO PROTECT, http://www.un.org/en/genocideprevention/crimes-against-humanity.html.

${ }^{30}$ The ISIS Genocide Declaration: What Next?: Hearing before the Subcomm. On Africa, Global Health, Global Hum. Rights, and Int'l Org., 114th Cong. (2016).

${ }^{31} I d$.

${ }^{32}$ Genocide Convention, supra note 29 , at art. 1.
} 
stated, “"'Wherever men and women are persecuted because of their race, religion, or political views, that place must - at that moment - become the center of the universe." 33

\section{II - Raphael Lemkin and the Creation of "Genocide"}

In the wake of the Holocaust, the world recoiled and quickly found that there was no word, no crime, to describe the abject horror of the "Final Solution". Winston Churchill himself would describe the world as coming face to face with a "crime that has no name" in $1941 .^{34}$ Though certainly history had been littered with atrocities prior to the Third Reich, World War I itself possessing a cruelty that would shape literature and art throughout the twentieth century, the enormity and precision of the Nazi crimes made the Holocaust different from everything prior. The industrialization of mass murder was something entirely different, something deserving of a greater crime that did not yet exist.

The term "genocide" was created by Raphael Lemkin, a lawyer of Polish Jewish descent whose efforts to seek justice for victims of the Holocaust and other conflicts have long gone uncelebrated. ${ }^{35}$ As a child, Lemkin had been horrified by reports of the massacre of Armenians within the Ottoman Empire, unable to comprehend why they had been killed simply on account of being Christian. He was further disturbed by the realization that those responsible for the massacre had not been held accountable for their crimes. ${ }^{36}$ In contrast, a young Armenian who had witnessed the murder of his family was immediately prosecuted after shooting Talaat Pasha,

\footnotetext{
${ }^{33}$ Elie Wiesel, Noble Peace Prize Acceptance Speech (Dec. 10, 1986).

${ }^{34}$ Tom Brooks, Raphael Lemkin: The man who coined the word 'genocide', BBC CULTURE (Nov. 20, 2014), http://www.bbc.com/culture/story/20141120-shining-a-light-on-genocide.

${ }^{35}$ Seth Augenstein, Forgotten Rutgers prof who coined 'genocide' now getting his due, NJ.COM (Apr. 12, 2015), http://www.nj.com/opinion/index.ssf/2014/04/the_man_who_named_horror_forgotten_rutgers_pro f_coined_genocide_now_getting_his_due.html.

${ }^{36}$ Coining A Word And Championing A Cause: The Story of Raphael Lemkin, THE U.S. HOLOCAUST MEMORIAL MuSEUM, https://www.ushmm.org/wlc/en/article.php?ModuleId=10007050 (last visited Mar. 5, 2018).
} 
one of the three de facto rulers of the Ottoman Empire at the time. ${ }^{37}$ This led Lemkin to ask his mother, with haunting foreshadowing, "Why is the killing of a million a lesser crime than the killing of a single individual?"38

Years later as a young lawyer, Lemkin went to his law professor to ask why the architects of the Armenian massacre had gone unpunished and encountered the issue of absolute sovereignty that had historically been a core concept of international law. The law professor, mirroring the debates that would later arise about genocide and state sovereignty, stated that because the Turks ruled the Ottoman Empire, they were allowed total sovereignty within their borders. In a chilling analogy that represented the longstanding view on the subject, the law professor analogized the Armenian crisis to a farm, comparing the murdered Armenians to chickens and the Turks to the owners of the farm. Because the chickens were held within the farm, the farmers could do whatever they wished to the chickens. ${ }^{39}$ In response, Lemkin wrote in his journal that "Sovereignty, I argued, cannot be conceived as the right to kill millions of innocent people." 40

In 1933, he submitted a paper to the Madrid meeting of the League of Nations that advocated for the international community to criminalize targeted acts against minority populations. Acts of barbarity, Lemkin argued, constituted violence aimed at minority groups, be they ethnic, religious or cultural, and included such as pogroms, massacres and "exterminations." 41 Acts of vandalism would occur when there was a systematic destruction of the cultural heritage, including works of art, science and literature. ${ }^{42}$ Lemkin further noted that the loss of such heritage would result in all of humanity suffering, not simply the culture in question. ${ }^{43}$ Furthermore, Lemkin argued that both acts posed a threat to the international

\footnotetext{
${ }^{37}$ Raphael Lemkin, WATCHERS OF THE SKY, http://watchersofthesky.com/raphael-lemkin/ (last visited Feb. 17, 2018) [hereinafter Watchers].

${ }^{38} I d$.

${ }^{39}$ Nina Strochlich, The Man Who Invented the Word 'Genocide', THE DAILY BEAST (Nov. 19, 2014), https://www.thedailybeast.com/the-man-who-invented-the-word-genocide.

${ }^{40} I d$.

${ }^{41}$ Raphael Lemkin, Acts Constituting a General (Transnational) Danger Considered as Offences Against the Law of Nations, PREVENT GENOCIDE INTERNATIONAL (1933), http://www.preventgenocide.org/lemkin/madrid1933-english.htm.

${ }^{42} I d$.

${ }^{43} I d$.
} 
community, not simply the nations engaged in the aforementioned acts, and in subsequently deserved status as a recognized, international crime. ${ }^{44}$ At the time, other recognized international crimes included such as piracy, slavery and drug trafficking, but the League refused to vote on the issue. ${ }^{45}$ It was against this loss that Lemkin watched the rise of the Nazi Party with growing unease, eventually fleeing to the United States in 1941, but was unable to convince his parents to flee with him. ${ }^{46}$

Lemkin began to teach at Duke University and in 1944, the word "genocide" first appeared in print. His book, Axis Rule in Occupied Europe, devoted a chapter to the new concept of genocide in his critique and evaluation of the Third Reich. ${ }^{47}$ Even from first introduction, Lemkin purposefully structured the philological roots of genocide to mirror existing crimes, to fit easily into an existing compendium of legal language. His notebooks contain the scribblings of someone utterly focused on forging the perfect word, with such as "ethnocide" and "vandalism", which he had proposed in his League of Nations report a decade prior, crossed out. ${ }^{48}$ Upon settling on "genocide", Lemkin described the roots of the word he had created, stating it was melded together from the Greek word genos, meaning tribe or race, and the Latin word for killing, cide.Lemkin intended for genocide to directly parallel the formation of other crimes, such as fratricide, tyrannicide or homicide. ${ }^{49}$

\footnotetext{
${ }^{44} I d$.

${ }^{45} \mathrm{Id}$.

${ }^{46}$ Watchers, supra note 38.

${ }^{47}$ Raphael Lemkin, Axis Rule in Occupied Europe: Laws of Occupation - Analysis of Government - Proposals for Redress, PREVEnT GENOCIDE InTERNATIONAL (1944), http://www.preventgenocide.org/lemkin/AxisRule1944-1.htm [hereinafter Axis Rule].

${ }^{48}$ Raphael Lemkin and the Quest to End Genocide, CENTER FOR JEWISH HISTORY, https://artsandculture.google.com/exhibit/AQJNMxJ8 (last visited Dec. 29, 2017). ${ }^{49}$ Axis Rule, supra note 47.
} 


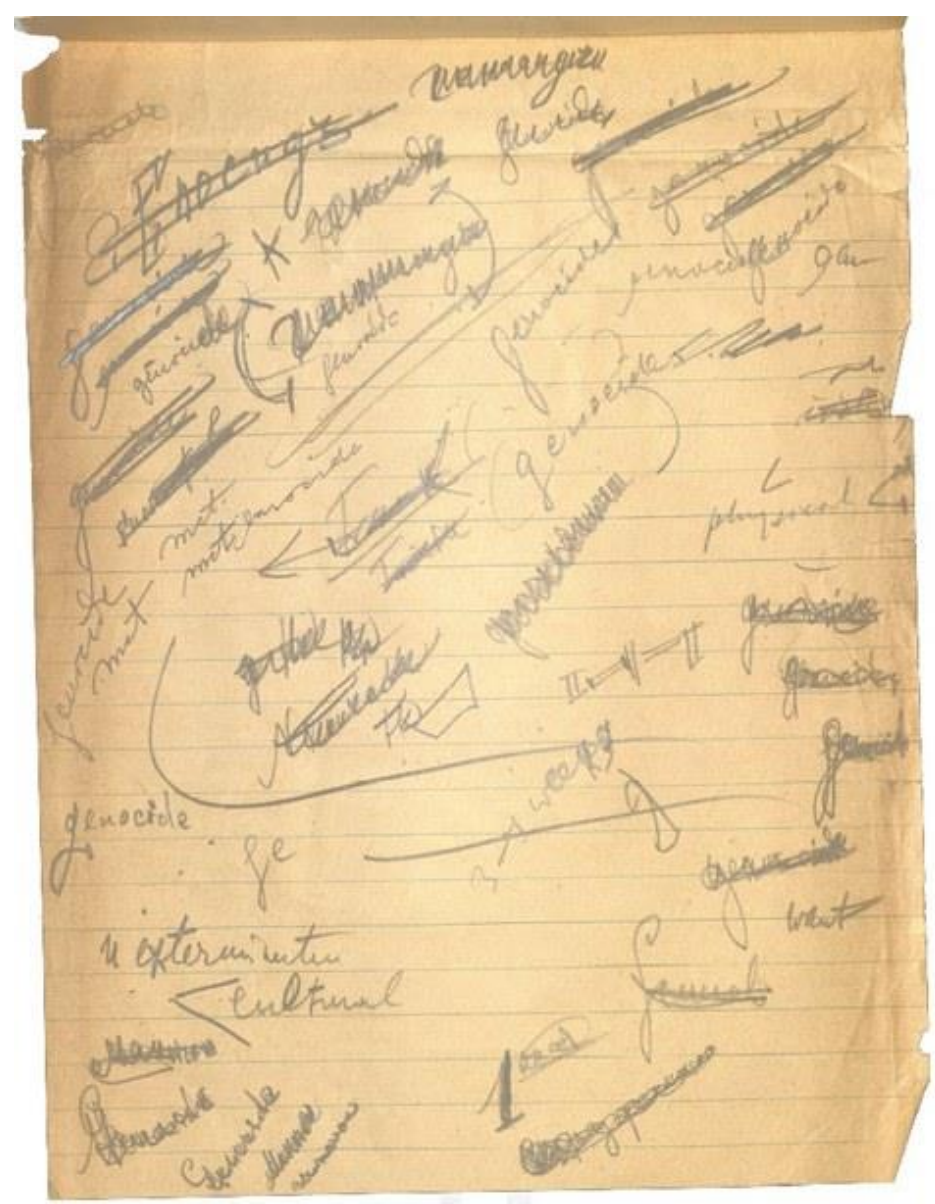

Photo taken from Raphael Lemkin's notebooks. ${ }^{50}$

However, as opposed to the strict legal definition that would later arise, Lekmin first introduced genocide as a broad concept, writing within Axis Rule that "genocide does not necessarily mean the immediate destruction of a nation, except when accomplished by mass killings of all members of a nation. It is intended rather to signify a coordinated plan of different actions aiming at the destruction of essential foundations of the life of national groups, with the aim of annihilating the groups themselves. The objectives of such a plan would be disintegration of the political and social institutions, of culture, language, national feelings, religion, and the economic existence of national groups, and the destruction of the personal security, liberty, health, dignity, and even the lives of the individuals belonging to such groups. Genocide is

${ }^{50}$ Cullen Murphy, 5 Questions for Phillipe Sands Ahead of His Nazi-Era Saga East West Street, VANITY FAIR (May 27, 2016), https://www.vanityfair.com/culture/2016/05/phillipe-sands-eastwest-street-nazi-genocide. 
directed against the national group as an entity, and the actions involved are directed against individuals, not in their individual capacity, but as members of the national group." ${ }^{, 51}$ It is worth noting that here, Lemkin's definition of genocide seems akin to the popular conception of genocide, not so much as a specific intent crime but rather the violent targeting of a minority, including religion, customary practices, and language.

Lemkin would go on to further refine the concept of genocide in an articles released in 1945, called "Genocide: A Modern Crime", that presented a summarized version of his argument in Axis Rule. "G2،Genocide: A Modern Crime" took specific aim at Third Reich for instituting "ancient barbarity" as a pillar of the German identity, for implementing government policy intentionally designed to eradicate Jews and other minorities. ${ }^{53}$ Lemkin's article further broke down the various factors that he believed contributed to the "techniques" of genocide, including the Cultural, Biological, Religious and Moral. ${ }^{54}$ Furthermore, he detailed the notion that genocide, by nature, should be thought of as an international crime. Lemkin wrote that genocide impacted the most primary interactions of civilized states, from injuring international trade opportunities, to undermining legal foundations, to creating instances of mass flight and migration. ${ }^{55}$

Despite addressing international concerns regarding trade and migration, Lemkin's final argument centered on what might be considered a moral argument, opposed to one political or economic in nature. He wrote that "Our whole cultural heritage is a product of the contributions of all peoples. We can best understand this if we realize how impoverished our culture would be if the so-called inferior peoples doomed by Germany, such as the Jews, had not been permitted to create the Bible or to give birth to an Einstein, a Spinosa; if the Poles had not had the opportunity to give to the world a Copernicus, a Chopin, a Curie, the Czechs a Huss, and a Dvorak; the Greeks a Plato and a Socrates; the Russians, a Tolstoy and a Shostakovich."

\footnotetext{
${ }^{51} I d$.

${ }^{52}$ Raphael Lemkin, Genocide - A Modern Crime, Prevent Genocide InTERnATIONAL (1945), http://www.preventgenocide.org/lemkin/freeworld1945.htm [hereinafterModern Crime].

${ }^{53} \mathrm{Id}$.

${ }^{54} I d$.

${ }^{55} \mathrm{Id}$.

${ }^{56} I d$.
} 
A year later, Lemkin published another article within American Scholar entitled "Genocide" in which he began to piece together the fundamental aspects of the crime of genocide. The very first section of the article implicitly addresses the recognition that the crimes of the Third Reich were something previously unconceived of, something warranting the creation of a new type of crime. Lemkin titled the section "A crime without a name" in reference to Winston Churchill's famous statement in $1941 .^{57}$ Writing that mass murder was simply inadequate to describe the breadth and depth of Nazi cruelty, Lemkin once more explained the roots of the word "genocide" and its existing counterparts within the legal dictionary.

Lemkin recognized that no state would prosecute or investigate itself for its own crimes, that genocide "by its very nature it is committed by the state or by powerful groups which have the backing of the state." ${ }^{58}$ Therefore, Lemkin argued, genocide had no place as a national crime but instead as one international. ${ }^{59} \mathrm{He}$ forged his concept of an international framework as one dependent on international cooperation for enforcement and adherence. ${ }^{60}$ Further harkening back to commonly held acceptances and concepts, Lemkin stated that international crimes were already present within the legal codes of most nations through such as laws against piracy, slavery and narcotics, an argument he had introduced in his 1933 report. ${ }^{61}$ Those accused of an international crime could also be tried within a country where the crime had not been committed, such as a currency forger who committed his crime in Paris and escaped to Prague can be punished validly in the latter city." ${ }^{2}$ Lastly, Lemkin addressed the concerns of the ex post facto law that would come to plague the Nuremberg trials by arguing that the failed adoption of a proposal within the League of Nations would have created a crime similar to his own conceptions of genocide and, subsequently, there would be no need for the ongoing concerns and implications on international law. ${ }^{63}$

\footnotetext{
${ }^{57}$ Raphael Lemkin, Genocide, PREVENT GENOCIDE InTERNATIONAL (1946), http://www.preventgenocide.org/lemkin/americanscholar1946.htm.

${ }^{58} I d$.

${ }^{59} I d$.

${ }^{60} I d$.

${ }^{61} I d$.

${ }^{62} I d$.

${ }^{63} I d$.
} 
It was with this intense devotion to international accountability that Lemkin approached the Nuremberg Trials, armed only with his new word and with the loss of millions of Jews weighing on his spirit.

\section{III -Nuremberg Trials}

International law had been a recognized idea prior to the Nuremberg Trials, with international norms decrying and criminalizing such as the aforementioned piracy and slavery, but international law focused on creating norms and standards leading up to the second World War had been largely unsuccessful. ${ }^{64}$ The Hague Conventions in 1899 and 1907 had been focused on determining the aforementioned regulations for warfare, but many nations in attendance were immediately wary of any restraint on state sovereignty. ${ }^{65}$ Furthermore, many of the agreed upon norms were ignored during the course of WWI by signatory states. The German invasion of Belgium in 1914, for example, came without warning or notice to the Belgian government. ${ }^{66}$ Subsequently, it was in direct violation of Article I of the 1907 Convention, which stated that "The Contracting Powers recognize that hostilities between themselves must not commence without previous and explicit warning, in the form either of a reasoned declaration of war or of an ultimatum with conditional declaration of war." ${ }^{\circ 7}$ Additionally, the 1899 Convention explicitly banned the use of "poison or poisoned arms" within Article 23. ${ }^{68}$ However, poison gas was introduced by German forces in 1915 in direct contravention of the Convention. ${ }^{69}$

Still, as the full extent of the horrors of the Holocaust slowly began to emerge throughout the early 1940s, there was the sense that international law was to play some role, however slight, in ensuring justice. Representatives of occupied European countries issued a declaration in 1942

\footnotetext{
${ }^{64}$ The Influence of the Nuremberg Trial on International Law, ROBERT H. JACKSON CENTER, https://www.roberthjackson.org/speech-and-writing/the-influence-of-the-nuremberg-trial-oninternational-criminal-law/ (last visited Dec. 18, 2017).

${ }^{65} I d$.

${ }^{66}$ Sophie de Schaepdrijver, The 'German Atrocities' of 1914, BRITISH LIBRARY (Jan. 29, 2014), https://www.bl.uk/world-war-one/articles/civilian-atrocities-german-1914.

${ }^{67}$ Laws of War: Opening of Hostilities (Hague III), Oct. 18, 1907.

${ }^{68}$ Convention with Respect to the Laws and Customs of War on Land (Hague II), July 29, 1899.

${ }^{69}$ Germans Introduce Poison Gas, HISTORY, https://www.history.com/this-day-inhistory/germans-introduce-poison-gas (last visited Dec. 18, 2017).
} 
that listed "among their principal war aims the punishment, through the channels of organized justice, of those guilty or responsible for these crimes, whether they have ordered them, perpetrated them, or in any way participated in them." ${ }^{70}$ The inclusion of "channels of organized justice" appeared to present something new, something not yet created, but nonetheless ensured that justice was to play a role within the aftermath of the war. ${ }^{71}$

Raphael Lemkin, who was eager to install genocide within international legal frameworks, managed to secure a position within the US delegation as the Trials approached. ${ }^{72}$ Lemkin must also have been ecstatic to hear that genocide was widely used to describe Nazi actions, being used within Justice Robert Jackson's memorandum for the London Conference in June of $1945 .^{73}$ Within the memorandum, Jackson had outlined the evidence he intended to use within the Trials and included "[g]enocide or destruction of racial minorities and subjugated populations by such means and methods as (1) underfeeding; (2) sterilization and castration; (3) depriving them of clothing, shelter, fuel, sanitation, medical care; (4) deporting them for forced labor; (5) working them in inhumane conditions." 74 However, genocide was met with hesitance by lawyers from other Allied nations, with the British delegation supposedly wary of the fact that genocide was not included or defined within The Oxford English Dictionary. ${ }^{75}$

However, the inclusion of genocide would eventually shift to a new meaning throughout the course of the Nuremberg Trials. The primary charges leveled against the defendants consisted of four crimes detailed in Article 6, "(1) Conspiracy to commit charges 2, 3, and 4, which are listed here; (2) crimes against peace-defined as participation in the planning and waging of a

${ }^{70}$ GeOrge Ginsburgs \& V.N. KudriavtseV, The Nuremberg TRIAL AND InTERnAtional LAW 13 (1990).

${ }^{71} I d$.

${ }^{72}$ John Q. Barrett, Raphael Lemkin and 'Genocide' At Nuremberg, THE GENOCIDE CONVENTION SIXTY YEARS AFTER ITS ADOPTION (2010),https://www.stjohns.edu/sites/default/files/documents/law/john-q-barrett/raphaellemkin.pdf.

${ }^{73}$ William Schabas, Origins of the Genocide Convention: From Nuremberg to Paris, 40 CASE WESTERN RES. J. OF INT'L LAW (2007), https://scholarlycommons.law.case.edu/cgi/viewcontent.cgi?referer=https://www.google.com/\&h ttpsredir $=1 \&$ article $=1273 \&$ context $=$ jil.

${ }^{74} I d$.

${ }^{75}$ Hilary Earl, Prosecuting genocide before the Genocide Convention: Raphael Lemkin and the Nuremberg Trials, 15 JOURNAL OF GENOCIDE RESEARCH 317, 322 (2013). 
war of aggression in violation of numerous international treaties; (3) war crimes - defined as violations of the internationally agreed upon rules for waging war; and (4) crimes against humanity_-namely, murder, extermination, enslavement, deportation, and other inhumane acts committed against any civilian population, before or during the war; or persecution on political, racial, or religious grounds in execution of or in connection with any crime within the jurisdiction of the Tribunal, whether or not in violation of domestic law of the country where perpetrated." 76 Much to Lemkin's disappointment, there was no mention of genocide within the fourth count of “crimes against humanity", an area he surely must have felt genocide belonged.

Although Lemkin's construction of genocide seemed to permeate the understanding and discussions of crimes against humanity throughout the Trials, the International Military Tribunal's (IMT) shift to crimes that had only taken place during the war, and not independent of in response to concerns regarding jurisdiction. ${ }^{77}$ The IMT focused the four charges in connection with the war itself, all four Allied delegations insisting on a connection between the crimes and the war itself started by Germany that came to be known as the "nexus of war" theory. ${ }^{78}$ In short, the Allied nations, in particular the US and the United Kingdom, were wary of the possibility of charges being brought against countries for actions within their own borders taken during wartime and instead sought to connection the four charges to the war. ${ }^{79}$ This worry was voiced by Justice Jackson himself, who noted that "Ordinarily we do not consider that the acts of a government toward its own citizens warrant our interference. We have some regrettable circumstances at times in our own country in which minorities are unfairly treated." 80 The IMT furthermore drew a distinction between the pre-war acts Germany took against Jews and other minorities and those enacted during the war, with none of the accused being found guilty of any crime taking place prior to the start of the war in $1939 .{ }^{81}$

\footnotetext{
${ }^{76}$ Charter of the International Military Tribunal, art. 6 [hereinafter IMT Charter]. ${ }_{77}^{7}$ Schabas, supra note 71 , at 44.

${ }^{78} I d$.

${ }^{79}$ Hirad Abtahi, Crimes Against Humanity and the Armed Conflict Nexus: From Nuremberg to the ICC, EUROPEAN SOCIETY OF INT'L L. (2013), https://papers.ssrn.com/sol3/papers.cfm?abstract_id=2363608\#\#.

${ }^{80}$ Kristin HENRARD \& ROBERT DUNBAR, SYNERGIES IN MiNORITY PROTECTION 207 (2008).

${ }^{81}$ Schabas, supra note 71
} 
In the judgement regarding Count 4, crimes against humanity, the International Military Tribunal specifically stated that the vast terror of the Third Reich had undoubtedly begun prior to the war and that untold horror had been inflicted upon the Jewish people through it, but "to constitute crimes against humanity, the acts relied on before the outbreak of war must have been in execution of, or in connection with, any crime within the jurisdiction of the Tribunal. The Tribunal is of the opinion that revolting and horrible as many of these crimes were, it has not been satisfactorily proved that they were done in execution of, or in connection with, any such crime. The Tribunal therefore cannot make a general declaration that the acts before 1939 were crimes against humanity within the meaning of the Charter..." 82

Nonetheless, it is undeniable that Lemkin's construction and concept of genocide impacted the Trials. During one trial against a Nazi doctor accused of crimes against humanity for experiments on Jewish victims, Lemkin's "medical technique" of genocide was invoked as prosecutors connected the experiments to the larger goal of the eradication of minority groups throughout the Third Reich. ${ }^{83}$ British, French and Soviet prosecutors all made explicit mention to genocide throughout the trial proceedings. ${ }^{84}$ Still, the absence of genocide specifically and the required connection of crimes against humanity to wartime would posit genocide as a crime solely in conjunction with war, not something that could occur within the absence of war. This requirement made it difficult, if not altogether impossible, to hold nations accountable for actions taken within their own borders. However, many prosecutors found themselves discontented with this conclusion and despite the initial concerns of the Allied nations, sought to create a way to remedy this only a few years later. ${ }^{85}$

\section{U.N. Convention on Genocide}

Whatever frustration Lemkin may have felt in the wake of Nuremberg was surely lessened when the United Nations decided to hold a convention specifically on genocide. Lemkin had lobbied member states to not only declare genocide a crime and one separate from the

82Judgement: The Law Relating to War Crimes and Crimes Against Humanity (1946).

${ }^{83}$ Earl, supra note 75 , at 328.

${ }^{84}$ Barrett,supra note 72 , at $47,51$.

${ }^{85} \mathrm{Id}$. 
"nexus" of war adopted by the Allied nations during Nuremberg, but additionally to create a treaty that would hold states accountable for instances of genocide. ${ }^{86}$

In 1946, during the first session of the UN General Assembly, member states Cuba, Panama and India presented a draft resolution that reflected Lemkin's goals and counteracted the "nexus of war" theory of genocide. ${ }^{87}$ The draft resolution presented two main ideas. The first was that genocide could be committed within peacetime as well as within war, a distinction that openly revoked the "nexus of war" at Nuremberg. The second called for genocide to be subjectto universal jurisdiction, a concept in line with Lemkin's recognition that no country would prosecute itself for genocide. ${ }^{88}$

Universal jurisdiction is a concept central to international law but one that also presents no small amount of wariness. After all, international law presents the constant tension between national sovereignty and global accountability. Universal jurisdiction is the concept that a perpetrator of a serious crime against international law, a longheld example of which was piracy, may be prosecuted within a national court. ${ }^{89}$ Furthermore, a national court may hear such a case even if the crime did not take place within the nation or did not impact it. The national court may also prosecute government leaders of other, sovereign states under the theory. ${ }^{90}$ The first aspect of the draft resolution was signed into law as General Assembly Resolution 96 (I) on December 11, 1946 but contained no mention of universal jurisdiction and whether genocide could be committed during peacetime, but did recognize it as a crime. ${ }^{91}$ However, and most importantly, the Resolution called for a draft convention on the crime of genocide to further define it. ${ }^{92}$ Not surprisingly, Lemkin personally lobbied to be included within the drafting and was designated one of three experts during its writing. ${ }^{93}$

\footnotetext{
${ }^{86} I d$.

${ }^{87}$ William Schabas, Convention on the Prevention and Punishment of the Crime of Genocide, U.N. AUDIOVISUAL LIBRARY OF INTERNATIONAL LAW, http://legal.un.org/avl/ha/cppcg/cppcg.html (last visited Feb. 9, 2018).

${ }^{88} I d$.

${ }^{89}$ Universal Jurisdiction, International Justice Resource Center, ${ }^{89} \mathrm{http}: / / \mathrm{www} . \mathrm{ijrcenter} . o r g /$ casesbefore-national-courts/domestic-exercise-of-universal-jurisdiction/ last visited (Dec. 17, 2018). ${ }^{90} I d$.

${ }^{91}$ Schabas, supra note 87

${ }^{92} \mathrm{Id}$.

${ }^{93} I d$.
} 
Two year later, the Convention on the Prevention and Punishment of the Crime of Genocide permanently instilled genocide as not only a recognized concept, but a crime under international law. The Preamble makes explicit reference to genocide as not only a crime against international law, but one that requires international cooperation to prevent and stop by stating "Being convinced that, in order to liberate mankind from such an odious scourge, international co-operation is required..." ${ }^{94}$ As mentioned within Section I of this paper, this mandate is, in part, why states are often slow to officially declare a conflict an instance of genocide and why the politics surrounding a declaration of genocide can quickly become murky. ${ }^{95}$

Furthermore, and critically, the Convention instilled the legal principle that genocide may take place during a time of war or in peace in direct response to the criticism of Nuremberg. Article 1 states that "the Contracting Parties confirm that genocide, whether committed in time of peace or in time of war, is a crime under international law which they undertake to prevent and to punish." ${ }^{96}$ Universal jurisdiction, however, was explicitly rejected and subsequently, the ongoing issue of jurisdiction made all the more confusing. Article 6 of the Convention recognized territorial jurisdiction which allowed for states to try citizen defendants, but also allowed for jurisdiction through an international tribunal accepted by signatory states. ${ }^{97}$ However, there existed no international tribunal at the time of the Convention.

In response, the General Assembly requested that the International Law Commission, a U.N. body designated to create international law norms and customary practice, research and begin to construct an international tribunal to try those accused of genocide. ${ }^{98}$ This work was unfortunately slowed and largely ignored during the next few decades as the Cold War began to

${ }^{94}$ G.A. Res. 260 A (III), Convention on the Prevention and Punishment of the Crime of Genocide (Dec. 9, 1948) [hereinafter Genocide Convention].

${ }^{95}$ Samantha Power, Bystanders to Genocide, The Atlantic (Sept. 2001), https://www.theatlantic.com/magazine/archive/2001/09/bystanders-to-genocide/304571/. For more regarding the U.S. response to labeling conflicts genocide, see A Problem from Hell by Samantha Power, the author of this article. She would later go on to become the U.S. ambassador to the United Nations.

${ }^{96}$ Genocide Convention, supra note 93, at art. 6.

${ }^{97} I d$.

${ }^{98}$ History of the Rome Statute of the International Criminal Court, CANADA'S HuMAN RIGHTS COMMITMENTS (Dec. 3., 2015) http://humanrightscommitments.ca/2015/12/history-of-the-romestatute-of-the-international-criminal-court/. 
churn and attempts at creating a tribunal and codified crimes stalled. ${ }^{99}$ This was remedied with the adoption of the "Rome Statute" in 1998, which created the International Criminal Court and in 2002, the Court entered into force. ${ }^{100}$ Finally, within the statute and embedded in Article 6, lay the definition of genocide not only for the purpose of official legal codification, but for the pursuit of international accountability that a young Raphael Lemkin had desperately advocated for almost a century earlier. ${ }^{101}$

\section{Conclusion}

Just as any legal principle or any of focus is better understood through a historical examination, genocide as a legal concept becomes all the clear by looking at its creation and its development in the wake of the Holocaust and at the dawn of the Cold War. Many of the nuances and areas of disagreement surrounding genocide, including issues of sovereignty, jurisdiction, and connection with war began in the initial discussions and charges of the Nuremberg Trials and remain disagreements today. While some of the work proposed by Raphael Lemkin has been accomplished, such as the recognition of genocide as an international crime, there is still much be done in preventing genocide and seeking justice for its victims. The first step, however, lays in truly understanding what we seek to prevent.

Submetido em: 02/09/ 2018

Aprovado: 17/09/2018

\footnotetext{
${ }^{99} I d$.

${ }^{100} I d$.

${ }^{101}$ Rome Statute of the International Criminal Court, art. 6 (July 17, 1998). 